perature, disproportionating rapidly into $\mathrm{SiF}_{4}$ and $\left(\mathrm{C}_{2} \mathrm{H}_{5} \mathrm{O}\right)_{2} \mathrm{SiF}_{2}$. The disproportionation proceeds to about one third of completion, at which point an equilibrium is set up. However, the compound can easily be purified by high-vacuum distillation at low temperature and pressure. The solid melts at $-122^{\circ}$. The diethoxy compound is also unstable by disproportionation; even when distilled in high vacuum at temperatures in the neighbourhood of $-30^{\circ}$, it disproportionates about one eighth of the total into $\mathrm{SiF}_{4}$ and one eighth into $\left(\mathrm{C}_{2} \mathrm{H}_{5} \mathrm{O}\right)_{3} \mathrm{SiF}$ at each distillation. Peppard, Brown and Johnson probably failed to note this compound as unstable, because of the circumstance that they distilled it only once with a long column; had they repeated the distillation, they would have observed the disproportionation. The triethoxy compound is the most stable of the three, having no tendency to disproportionate even at temperatures near its boiling point. The boiling point is $134 \cdot 6^{\circ}$, by extrapolation from the vapour pressure curve. This agrees reasonably well with the American authors' figure of $133^{\circ}-133 \cdot 5^{\circ}$.

The monoethoxy compound was prepared by fluorinating $\left(\mathrm{C}_{2} \mathrm{H}_{5} \mathrm{O}\right) \mathrm{SiCl}_{3}$ with $\mathrm{SbF}_{3}$, and the other two by fluorinating $\left(\mathrm{C}_{2} \mathrm{H}_{5} \mathrm{O}\right)_{3} \mathrm{SiCl}$ with $\mathrm{SbF}_{3}$. Reaction is vigorous and no catalyst is needed. Disproportionation occurs during the fluorination (whence the possibility of preparing $\left(\mathrm{C}_{2} \mathrm{H}_{5} \mathrm{O}\right)_{2} \mathrm{SiF}_{2}$ from $\left(\mathrm{C}_{2} \mathrm{H}_{5} \mathrm{O}\right)_{3}$ SiCl), and a mixture of all three fluoro-compounds is formed when either of the chloro-compounds is fluorinated.

In attempting to prepare the three chloro-compounds by Friedel and Crafts' method, the mono- and tri-ethoxy compounds were easily obtained pure and stable to distillation, but the diethoxy compound disproportionated, and the whole fraction eventually resolved itself, on repeated distillation, into the monoand tri-ethoxy derivatives.

This work was carried out at the Imperial College of Science and Technology, under the direction of Dr. H. J. Emeléus.

Schärenmoosstrasse 18 ,

Seebach, Zurich 11 . Oct. 5.

${ }^{1} J$. Amer. Chem. Soc., 68, 76 (1946).

2 Ph.D. Thesis, University of London, 1942.

\section{Bactericidal Power of Electrolytic Hypochlorite}

IT has been long observed that hypochlorite liquor, freshly prepared by electrolysis of brine using carbon electrodes, possesses characteristic oxidizing properties distinct from chlorine water or from sodium hypochlorite prepared by the passage of chlorine into caustic soda solution. Masterman ${ }^{1}$ made an extensive survey of the possible differences, and, using tetramethyl base, showed that electrolytic hypochlorite produced quite a different range of dyestuff colours from either of the other two chlorine agents. He suggested that this might be due to the presence of ozone in the electrolysed solution, since a similar colour reaction is given by that substance.

Experimental work carried out in this laboratory in 1938 on the oxidation of aniline confirmed Masterman's differential findings, but no evidence of the presence of ozone could be demonstrated.

Electrolytic hypochlorite is a buffered solution containing free hypochlorous acid and sodium hypochlorite. Degradation of hypochlorous acid produces hydrochloric acid which liberates further hypo- chlorous acid. It is possible that this labile hypochlorous acid is responsible for the enhanced oxidizing powers. It is significant that commercial hypochlorite is stabilized by alkalinization to $p \mathrm{H} 10$, whereby free hypochlorous acid is neutralized.

Chlorine water, on the other hand, is still a solution of the gas (since the bulk of it may be removed by aspiration), and its oxidizing action probably occurs after chlorination of the reducing agent. A further suggestion that the electrolytic solution contains amounts of chlorites should also be borne in mind.

That there is a marked difference in the oxidation potential of the three substances may readily be demonstrated by their behaviour as bactericides to certain organisms.

In an experiment a large quantity of water was divided into four equal volumes in sterile containers, and to each was added a similar measured quantity of suspension of $B$. coli in water medium. These were then treated respectively with 2 p.p.m. 'available chlorine', of chlorine water, sodium hypochlorite solution (commercial) and electrolytic brine solution. The fourth acted as control. After given time intervals, samples were taken from each and the oxidizing agent 'killed' by addition of sodium thio. sulphate solution. Equal quantities of the samples were then plated out on lactose-agar medium and incubation carried out. In the accompanying table the figures represent indices of colonies of $B$. coli produced after 72 hours incubation.

\begin{tabular}{|c|c|c|c|c|}
\hline $\begin{array}{c}\text { Contact } \\
\text { time }\end{array}$ & $\begin{array}{c}\text { Commercial } \\
\text { hypochlorite }\end{array}$ & $\begin{array}{c}\text { Chlorine } \\
\text { water }\end{array}$ & $\begin{array}{c}\text { Electrolytic } \\
\text { hypochlorite }\end{array}$ & Control \\
\hline 0 min. & 10 & 10 & 10 & 10 \\
$3 \%$ & 7 & 7 & 7 & 10 \\
$6 \%$ & 5 & 5 & 2 & 10 \\
$15 \%$ & 3 & 4 & 0.5 & 10 \\
30, & 1 & 2 & nil & 10 \\
\hline
\end{tabular}

It will be seen that, for equal quantities of oxidizing agent as measured by arsenite-iodine titration, electrolytic hypochlorite has definitely a more rapid bactericidal effect. These tests have been carried out with a number of different organisms using varying concentrations, with or without ammonia being present. In every case it is observed that the electrolytic hypochlorite has a more rapid bactericidal effect.

23-24 Welbeck Way, London, W. 1 . Oct. 1 .

'Masterman, A. T., Analyst, 64, 492 (1939).

R. F. Milton

J. L. HoskIns

\section{Physiology in Horse-racing}

DEEMING the scientific world interested in all things, and competent to contribute useful help, I make no apology for introducing the subject of horseracing and the riding of races therein.

Horse-racing is not a particular hobby of mine, but I have been much struck on a visit to Ascot races by the fact that, whereas in sprints up to a mile all joekeys try to keep among the prominent horses throughout the race, relying on extra speed at the end to win, in long-distance races there seems to be almost competition to be last at the beginning in order to be first at the finish. I cannot believe that this is based on the Biblical adage, but that in the minds of the very shrewd people whose business it is to do these things, it is thought to show advantages. 